\title{
AIDS and jail: social representations of women in freedom deprivation situations*
}

\author{
Aids e cárcere: representações sociais de mulheres em situação de privação de liberdade \\ Sida y cárcel: representaciones sociales de mujeres en situación de privación de libertad
}

Débora Raquel Soares Guedes Trigueiro ${ }^{1,2}$, Sandra Aparecida de Almeida ${ }^{3}$, Aline Aparecida Monroe ${ }^{4}$, Gilka Paiva Oliveira Costa $^{5}$, Valéria Peixoto Bezerra ${ }^{6}$, Jordana de Almeida Nogueira ${ }^{6}$

How to cite this article:

Trigueiro DRSG, Almeida SA, Monroe AA, Costa GPO, Bezerra VP, Nogueira JA. AIDS and jail: social representations of women in freedom deprivation situations. Rev Esc Enferm USP. 2016;50(4):554-561. DOI: http://dx.doi.org/10.1590/S0080-623420160000500003

\author{
"Extracted from the thesis "Representações \\ sociais sobre aids e sexo entre mulheres \\ em situação de privação de liberdade”, \\ Universidade Federal da Paraíba, 2015. \\ ${ }^{1}$ Universidade Federal da Paraíba, \\ Programa de Pós-Graduação em \\ Enfermagem, João Pessoa, PB, Brazil. \\ ${ }^{2}$ Escola de Enfermagem Nova Esperança, \\ Programa de Mestrado Profissional em \\ Saúde da Família, João Pessoa, PB, Brazil. \\ ${ }^{3}$ Universidade Federal da Paraíba, Departamento \\ de Enfermagem em Saúde Pública e \\ Psiquiátrica, João Pessoa, PB, Brazil. \\ ${ }^{4}$ Universidade de São Paulo, Escola de \\ Enfermagem de Ribeirão Preto, Departamento \\ de Enfermagem Materno Infantil e Saúde \\ Pública, Ribeirão Preto, SP, Brazil. \\ ${ }^{5}$ Universidade Federal da Paraíba, Departamento \\ de Medicina Interna, João Pessoa, PB, Brazil. \\ ${ }^{6}$ Universidade Federal da Paraíba, Departamento \\ de Enfermagem Clínica, João Pessoa, PB, Brazil.
}

\begin{abstract}
Objective: To grasp the AIDS social representations built by freedom-deprived women. Method:Descriptive study with a quali-quantitative approach that involved 174 convicted women in a women's prison in a capital city of the Brazilian northeastern region. A word-association test was applied in October and November 2014, using AIDS as a stimulus. The corpus was processed using Iramuteq software. Descending Hierarchical Classification and Correspondence Factor Analysis were applied. Results: The content that comprises the social representation of AIDS was influenced by the prison context, which was pervaded by a lack of assistance, lack of knowledge, discrimination, and suffering that disclosed vulnerability to HIV/AIDS factors such as unprotected sex and object sharing. This underlines the stigma and fear of the illness, in addition to favoring and supporting negative feelings and a sense of rejection. Conclusion: To consider the use of this representational amalgam to ensure a comprehensive, contextualized care can help redirect practices, motivate self-care practices, and reduce prejudiced attitudes.
\end{abstract}

\section{DESCRIPTORS}

Acquired Immunodeficiency Syndrome; Prisoners; Women; Health Vulnerability. 


\section{INTRODUCTION}

Although one may recognize the advances in discussions, research, therapies, educational campaigns, and preventive programs regarding the transmission of the human immunodeficiency virus (HIV), not everyone has equal access to these resources and services. Throughout the years, the diversity in the infection distribution standard gave it various epidemiological configurations and resulted in expansion to marginalized groups that have less social support and fewer developmental opportunities.

This scenario has been shaping discriminatory practices and behaviors, strengthening the stigma and compromising programs that respond to HIV, hindering access to healthcare services on the part of those who live with HIV and those who face a high risk of contracting the virus ${ }^{(1)}$.

Among the priorities listed by the Declaration of Melbourne ${ }^{(1)}$ and the Brazilian Ministry of Health, measures and actions to fight the illness in its different manifestations and expressions must be strengthened in order to focus on the most vulnerable populations, including women and people deprived of freedom ${ }^{(2)}$. Among women, it is estimated that HIV infection is more prevalent in the context of prison $^{(3)}$.

The usual perspective of attributing a collective health state to individual behaviors creates difficulties for the implementation of prevention and control actions. It is necessary to invest in the quality of socio-cultural diagnoses of health problems, particularly when they lead to changes in socially established behaviors ${ }^{(4)}$.

The historical and social aspects of HIV infection, as well as its epidemic characteristics, have exerted a strong influence on behaviors and groups. At the onset of AIDS, the lack of medical-scientific information and the way the media took over this "unknown" evil gave it a life of its own in people's minds ${ }^{(5)}$. The media published heavily emotional stories characterized by death, contamination, and sex, favoring the rise of moral, social, and biological conceptions ${ }^{(6)}$.

Although there is a set of therapeutic procedures and a consequent change in the meaning of living with the infection, the social representations (SR) of AIDS still remain closely associated with exclusion and lack of morality. In societies where the infection affected women, this fact became typically associated with inappropriate sexual behavior, according to the local gender rules ${ }^{(7)}$.

Therefore, the focus of this study is to point out the characteristics of the subjective experience of women deprived of freedom. These characteristics will allow for organizing and analyzing SR of AIDS as latent knowledge that results from the mindset and ways of acting socially in unique shared realities, pointing to approaches to or withdrawals from the scientific definitions of AIDS from the standpoint of practical knowledge.

Upon consulting to the SciELO database, we found no studies that portrayed AIDS SR in the prison system. From this perspective, addressing women in prison is justified by the opportunity to understand the various ways of representing AIDS and attitudes in the face of this phenomenon ${ }^{(8)}$.
Therefore, this study's objective is to grasp the social representations of AIDS built by women deprived of freedom.

\section{METHOD}

This is an exploratory, descriptive study with a qualiquantitative approach, supported by the theoretical input of social representations (SR). Systematically, three dimensions are present in SR (information, image, and attitude) and there are two main socio-cognitive processes (objectification and anchoring). The information corresponds to the knowledge organization by a particular group concerning a social object, varying according to the amount and quality of this knowledge. The images comprehend the senses associated with the object, and the attitude refers to the stand one takes regarding the social representation object. Objectification, in its turn, explains how the elements represented by a theory integrate the social reality, and anchoring enables an understanding of the way through which these elements help reveal and form social relations ${ }^{(9)}$. Complementarily, as an analysis proposition to anchoring, four typologies are highlighted: psychological; psycho-sociological; sociological ${ }^{(10)}$; and biological/physical ${ }^{(11)}$.

This study was conducted at the Centro de Reeducação Maria Júlia Maranhão prison, located in the city of João Pessoa. This site was chosen because it is the only prison in the city and because it gathers the largest number of imprisoned women in the state of Paraíba. The population consisted of 268 imprisoned women in a closed system and the sample size was calculated through a statistic program (using the commands "Several means", ANOVA, 1-way). The parameters were as follows: probability $\alpha=0.05$; probability $\beta=0.20$; variation as error $=0.2$, with a correction of $10 \%$ for potential losses. The sample, thus, consisted of 174 women.

The participants were selected through non-probability convenience sampling (voluntary participation) and the inclusion criterion was to be sentenced in a closed system. It is important to mention that researchers did not have access to the prisoners' serological condition.

For data collection, a multiple choice structured questionnaire was applied, which contained sociodemographic information (age, race, marital status, religious belief, schooling, prison time) and a word-association test, whose inductive stimulus was the word "AIDS." This technique comprises an open inquiry that stimulates the elicitation of answers given from one or more inductive words. It allows for evidencing the semantic universes connected with the representation object ${ }^{(12)}$.

After formalizing the research with the Prison Administration State Secretary and obtaining consent from the institution's administrative coordinators, it was previously agreed that the data collection would take place in the prison classroom in the afternoon. As a standard, five inmates would be released at a time. By voluntary participation, prison guards escorted the women to the research site. After they had finished the test, the women returned to their cells. This process was repeated until the sample was complete. This procedure occurred in the months of October and November 2014. 
The instrument was applied individually by five previously trained and qualified researchers. Each participant received information on the nature and objectives of the study. Their participation occurred upon signing an Informed Consent. Before the introduction of the abovementioned stimulus, a simulation mas conducted with an example to make participants familiar with the instrument functionality. After that, the inductive stimulus was introduced, followed by the questions: What comes to your mind when I say the word AIDS? and Say the first five words that remind you of AIDS. The answers were recorded by the researchers.

The collected results comprised the corpus that was transcribed to the Word program, submitted to refinement for exclusion of word repetitions, grouping the words by semantic similarity, and the elaboration of a dictionary. Two researchers were called upon to validate the dictionary. After that, the information was processed by the literal analysis software Iramuteq (Interface de R pour les Analyses Multidimensionnelles de Textes et de Questionnaires, Version 0.6 alpha 3) to enable multivariate analyses, especially the descending hierarchical classification method and the correspondence factor analysis ${ }^{(13)}$.

A descending hierarchical classification $(\mathrm{DHC})^{(14)}$ qualified the text segments due to their respective vocabularies, analyzed the text lexicographically, and categorized five classes of answers associated with the stimulus "AIDS." Of the total 174 Initial Context Units (ICU) in the corpus, 122 Elementary Context Units (ECU) remained, selected in accordance with the values of $\left(x^{2}\right)$.

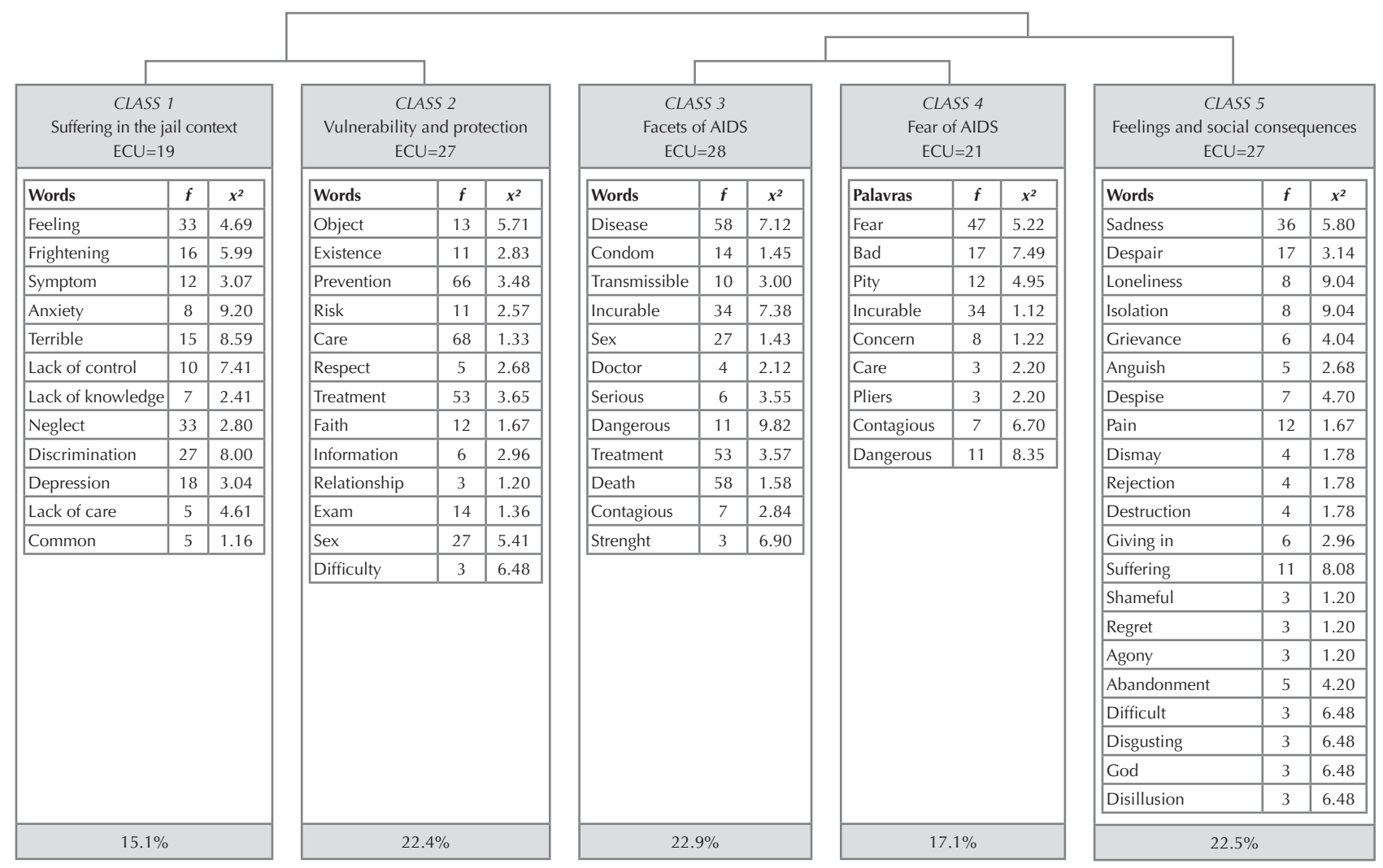

Figure 1 - Dendogram referring to the distribution of the class vocabulary according to Descending Hierarchical Classification in relation to the stimulus "AIDS" - João Pessoa, Paraíba, 2014.

As presented in the dendogram (Figure 1), the corpus was divided into two sub corpora. The first one, which originated in Class 5 and later in Classes 3 and 4, connects the "social feelings and consequences" related to AIDS to the "fear" that the illness causes and its multiple "facets." The second corpus, which constituted Classes 1 and 2, connects AIDS with "suffering in the jail context," and the elements that condition "vulnerability and protection" in terms of the disease.

Following the DHC, a correspondence factor analysis (CFA) was applied, which depicts the different words associated to each one of the DHC classes in a Cartesian plane. This interface allows for recovering in the original corpus the text segments associated with each class. At that moment, the context of the statistically significant words was obtained, enabling a more qualitative data analysis. It also enabled a detailed examination of the connection between individual answer profiles, expressing connections and oppositions and showing the existing bonds between different representational content in graphs ${ }^{(14)}$.

A parameter above $70 \%$ is considered a good use of the software (Version 0.6 alpha 3 ). The current study's relevance was $70.4 \%$ of the corpus.

The research project was approved by the Research Ethics Committee of the University Hospital Lauro Wanderley of the Paraíba Federal University, Opinion $n^{\circ}$ 660,127 . The study follows the guidelines of the research protocol described in resolution $466 / 2012$ by the National Health Council on research involving human beings. 


\section{RESULTS}

In the researched sample ( $\mathrm{n}=174)$, there was a predominance of $67.2 \%$ in the age range between 18 and 34 years old, mixed skin color (55.2\%), single (59.2\%), with up to eight years of schooling (70.1\%), and evangelical religion (42.5\%). As far as the prison time was concerned, 50.0\% had been serving their time for less than one year, 32.8\% between one and three years, and $17.2 \%$ had been in the closed system for more than three years.

Class one - suffering in the jail context concentrated $15.1 \%$ of the ECU. There was no evidence of a positive association in terms of inmates' age ranges. In this class, the content that comprise the AIDS SR is influenced by the prison context. Prison is a space where health care and necessary care are limited, both in terms of prevention and in terms of healing aspects, in addition to lack of care, neglect, and lack of knowledge about the disease. This produces discrimination against the people who live with HIV/ AIDS, a common feature in prison. Most of the prisoners know people infected with visible symptoms that can be observed because of the closely shared space that is typical of imprisonment situations, anchored in common aspects of the biological/physical dimension.

Attitudes about AIDS create the rejection seen at the interviews in prisoners' facial expressions even before they verbalized the reminders. Together with the prison situation, this becomes even more terrible and appalling, which results in suffering conditions such as lack of control, anxiety, and depression, in addition to feelings that have a psychological anchoring.

Class two - vulnerability and protection concentrated $22.4 \%$ of the ECU that remained. It was predominantly comprised of women between 35 and 49 years of age. This class includes elements that are connected to being infected with HIV in the prison context, characterized by situations that make them vulnerable - relationships, sex, and objects.

The determination of the disease, represented as an attribute of "risk behaviors," connects with sexual practices experienced by this group. Sex, as a consequence of relationships between inmates during their serving time, consists of unprotected practices homosexual (biological/physical dimension).

Another practical dimension of the AIDS SR associated with knowledge about contamination is characterized by object sharing. The most common practices mentioned in the prison environment and grouped in this category were: sewing needles; shaving razors; piercings; clamps; nail files; pliers; toothbrushes; underwear; toilet seats; cups; and silverware shared for routine use.

Regarding the HIV risk condition, this class also evoked positive elements that refer to care. Prevention measures, treatment, and faith were mentioned. In the reality of prison, from the perspective of protecting inmates' health, care is anchored in the physical/biological and psychological dimensions.

Prevention strategies integrate a set of practices and behaviors such as using condoms, not sharing objects, and knowing who you interact with. This shows that trusting the other is still a reason for not using condoms.

As far as treatment is concerned, the horror of immediate death seems to have been overcome. The development of new therapies capable of changing the infection into a chronic problem posed new challenges and changed the representational content.

Class three - facets of AIDS concentrated $22.9 \%$ of the ECU that remained. There was no significant association with the inmates' age range. The content of this class were not distant from the AIDS SR elaborated in the last few decades. The idea of contagious/transmissible illness that spreads mainly via sexual relations without condoms, feared by its nature as a serious and dangerous infection, requiring the figure of a doctor to establish a treatment that will prevent its most concerning aspect - being incurable and therefore leading to death - clearly shows a social mark or scar in the understanding of AIDS, affirming the anchoring of this representation in the sociological dimension.

Class four - fear of AIDS concentrated $17.1 \%$ of the ECU that remained. It was predominantly composed of women between 18 and 34 years of age. In this semantic context, the AIDS representation is anchored in the psycho-sociological dimension, mainly expressed by the feeling of fear. The idea that it is something bad and incurable, which gives people a sentiment of pity, inevitably leads to an imminent concern about having this type of problem.

Class five - social feelings and consequences concentrated $22.5 \%$ of the ECU. There was no significant association between the inmates' age ranges. It focuses mainly on negative feelings that emerge from the process of thinking about AIDS and from its social consequences. The socio-cognitive contents of psycho-sociological anchoring denote a negative view of the disease, associated with an image of despair, sadness, solitude, pain, suffering, destruction, and attitudes of rejection, disdain, disgust, abandonment, and isolation.

\section{ObJeCtification OF AIDS ACCORDING TO THE INTERVIEWED PRISONERS}

The AIDS objectification process presented in the graphs was elaborated from the AFC technique, allowing for visualization, under the configuration of a factor plan, of the oppositions that resulted from the DHC. In the two factors, the value of total variance was $64.86 \%$. Factor 1 , which corresponds to the horizontal axis, explained $35.85 \%$ of the total variance of answers. Factor 2 , which corresponds to the vertical axis, explained $29.01 \%$ of the total answers (Figure 2).

In the first factor (Axis 1), on the right side, the words that stand out are grouped in Class 1, which associates AIDS with negative feelings caused by the discrimination and lack of assistance that characterize imprisonment. The image of body degradation, as objectified by the expression symptom, remains, having contributed with $57 \%$ to explain this factor. In contrast, on the negative side of the same axis, the presence of the disease is translated into the feelings of sadness, despair, solitude, and isolation.

Still in the superior plane, on the right of the same axis, one can observe concern with the risk of catching 
the disease, represented by objects that are usually shared during imprisonment. In opposition to the risk factors, the precaution against sexual transmission would be the use of condoms, which contributed $50 \%$ to explain this factor.

Regarding the second factor (Axis 2), the transmissible characteristic of the disease and the unfeasibility of its cure demand care and prevention measures. This counters the occurrence of negative consequences such as suffering, disdain, abandonment, and rejection.

Fear, in prominence in the neutrality zone, may show that even though it expresses a significant element in the representation of the social stigma of AIDS, it does not shape a type of attitude by the interviewed female prisoners in terms of facing AIDS in their daily lives.

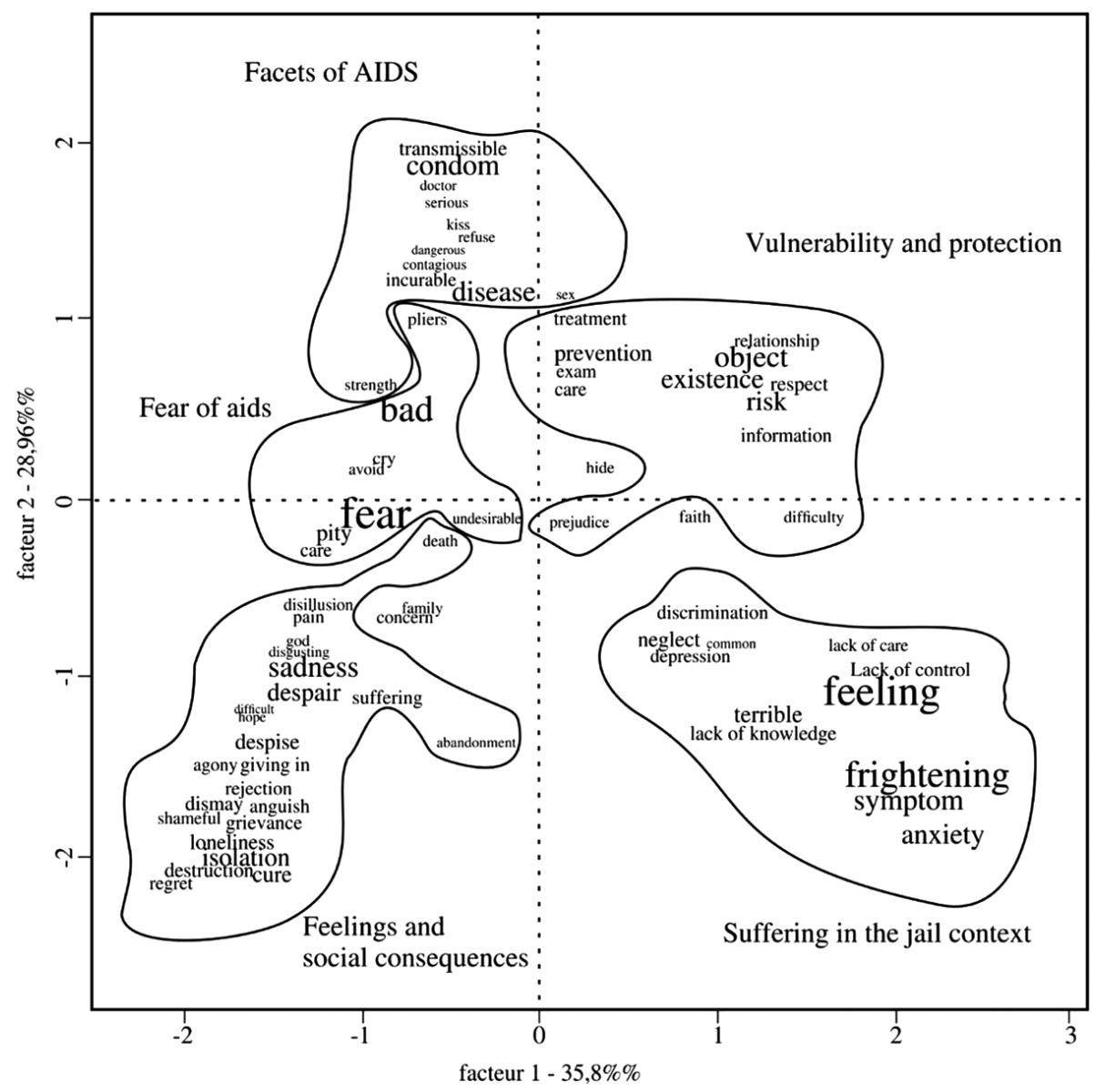

Figure 2 - Correspondence Factor Analysis with the representation of the coordinates (Axis 1 and 2), highlighting five classes and words with heavier factor loads - João Pessoa, Paraíba, 2014.

\section{DISCUSSION}

In the formation of the AIDS SR, influences from the media, the incipient scientific discoveries, and early medical knowledge from the onset of the epidemic shaped the stereotypes of the people who live with HIV/AIDS. In accordance with the reified knowledge about managing the disease, the information was spread by the press through images of weak people, and associated with the idea of death and the behaviors of risk groups ${ }^{(15)}$. This association opened up a space for the development of preconceptions against minorities, in addition to moral and social stigma that strengthened feelings of guilt ${ }^{(16-17)}$.

This attitude stresses that the initial limitation of medical information, proceeding from scientific research that demanded time, favored the social qualification of the disease. People elaborated their SR based on the information they had about ways of transmission and profiles of the people stricken. In agreement with the information that circulated in society, the SR were gradually elaborated by social groups, guiding the public's discriminatory behaviors based on socially and culturally constructed $\mathrm{SR}^{(16)}$.

Consequently, this lack of understanding and discrimination became obstacles that hinder or prevent access to health care. When a particular group suffers discrimination, abuse, and repression, there is a greater chance that they will not go for exams, prevention, or AIDS treatment services. The opposite behavior is also expected because the lack of assistance may lead to neglect, lack of knowledge, and discrimination, taking into account that one of these factors may influence the occurrence of another ${ }^{(1)}$.

Additionally, in the prison setting, structural limitations (physical inadequacy), population density, and poor hygiene and nutrition conditions limit healthcare opportunities and worsen suffering in the process of experiencing the disease, as seen in the first class. Although it is guaranteed by legal landmarks (National Health Plan for the Prison System; 
National Policy of Comprehensive Healthcare for Women), the fulfillment of the right to health among imprisoned women faces the impediments of prison logistics ${ }^{(18)}$.

The transmission risk, in its turn, is another expressive component in the representation of AIDS, as seen in Class 2. Regarding the contagion aspect, sex remains as the element that coexists between the reified universe and the consensual universe of AIDS. The impact of the alarming news of a new, unknown disease that was devastating and irreversible, with emphasis on the fact that it is sexually transmitted, transformed the worldwide sexuality scenario and produced turmoil in the way people face sexual activity.

However, the imprisoned women's perception of the possibility of being infected by HIV obeys the logic of the onset of the outbreak, when the idea of contamination via contact with an infected person's fluids would transmit the most feared disease of current times. There is no distinction between prejudice and veracity.

Research shows that there are still mistakes or solid mistaken beliefs in terms of ways of transmission. Some people marked insect bites, swimming pools, use of toilets, physical proximity, and sharing personal objects as ways of contamination, in addition to a superficial knowledge of AIDS prevention ${ }^{(8,19)}$.

Parallel to vulnerability, there is the need for care. Although mentioning it is a healthy observation, researchers must shed light on the fact that this is not enough to engender protective behaviors among individuals. This would require perception, understanding, assimilation, and the capacity to transform knowledge into practice, in addition to people's access to protective inputs, especially condoms, which are not available in prison.

When fighting illnesses, especially those socially marked as death sentences or extremely dangerous, faith poses as another mean of protection. Nevertheless, the exercise of spirituality in jail and faith in the divine cure show that the AIDS SR is marked by a polarity. On one hand, the illness is incurable according to the reified universe appropriation of thoughts. On the other hand, there is the belief in a cure associated with values and beliefs that are present in the common sense to bear the suffering.

Suffering does not occur solely as a result of the illness process, but it is also related to the facets of AIDS. These make up Class 3, according to the women prisoners, through key elements from which the social scar produced by this disease can be understood.

Illnesses can bestow social marks because of their devastating character. This may be the case when it comes to the destruction of Europe by the Black Plague; the frightening Spanish flu in the Twentieth Century; syphilis; leprosy; and finally cancer, which is seen as the plague of this century. However, none of these illnesses are as stigmatizing, according to society, compared to AIDS, which devastated thousands of people and produced irreversible consequences in the social, economic, and political spheres in a short period ${ }^{(20)}$.

To worsen the picture, facing the condition of women deprived of freedom, in total economic restriction, is like placing them in parallel places that are main universal sources of AIDS-related stigmatization and discrimination. There is the stigma related to sexuality, the stigma related to gender, the stigma related to race or ethnicity - which is paraphrased here as the groups where they belong - and the stigma related to economic marginalization or poverty ${ }^{(7)}$.

The irreversible nature of the consequences of AIDS is the worst characteristic of this disease: the fact that it is incurable. One can say that, in the general population's SR, AIDS is the illness that kills the most when compared to others. This springs from another strong binomial - AIDS and death - present in the hegemonic representation of the disease. For imprisoned women, it is no different. The AIDS $\mathrm{SR}$ carries the meaning of death and because it is associated with deprivation of freedom, it is considered a double punishment or a death sentenced twice. This creates fear of the illness, which stands out in Class 4.

The well-known "epidemic of fear" brought to the symbolic universe of AIDS various representations of fear: fear of the sick person; fear of being infected with the sick person's virus; fear of death; fear of physical changes; fear of prejudice and discrimination; and even fear of having fear $^{(21-22)}$.

Fear is part of human activity and can be an alert for danger; however, when people speak or think about AIDS, fear assumes a negative representational connotation because it is part of a twisted or unrealistic AIDS SR that still organizes reality in a haunting, unwise way.

It is necessary to rethink ways of fighting the fear that is so pervasive in the AIDS SR by various audiences that have maintained over time a proliferation of frightening meanings around the epidemic, which subtly hinder the ways to prevent or control the disease.

In summary, one's cognition in terms of the possibility of preventing a lethal illness feared by all and whose social consequences lead to a myriad of agonizing feelings ${ }^{(21,23)}$ of self-pity and self-destruction, is seen in Class 5.

This study highlights that, by gathering main consensual elements that integrate the AIDS SR - a frightening disease that causes suffering and fear when one thinks about HIV contamination, and is associated with socially reproachable behaviors (sex and drugs) - it is possible to understand the reasons that support the stereotype that forms the AIDS stigma, which consequently reproduces and stresses prejudices that favor marginalization and its social consequences ${ }^{(7,24-25)}$.

\section{CONCLUSION}

From the representational delimitation of AIDS in this study, it is possible to observe that improvements in including prison populations in public healthcare policies are not in compliance with the care practices provided in jail. Hegemonic representations of the epidemic onset still persist, loaded with mistaken information about the disease, favoring the threatening and destructive image of this infection, and supporting negative or discriminatory attitudes, in addition to negative feelings and difficulty in tackling the problem. Although some positions are crystallized regarding the object "AIDS" as an illness associated with death, it 
is possible to find the incorporation of new elements in its representations such as prevention, treatment, and increases in survival rates.

In the face of these reflections, this study warns of the need to rethink the logistics and guarantees for health care at all complexity levels, in addition to local actions that involve critical health education regarding the reality of the prison context. This will allow an opportunity for reflection on the social phenomenon through identification of inappropriate knowledge about the disease, demystifying prejudices, destroying discriminatory attitudes, and stimulating the adoption of protective attitudes regarding both physical and psychological health.

From this perspective of care in prison systems, the study also points to the need to make available some inputs that will be protective measures against HIV in activities that are indispensable to hygiene, self-care, and sexuality, such as cutting off cuticles and plucking hair, having a tattoo, ear piercing and other kinds of piercings, and having sexual intercourse. It is also necessary to raise this audience's awareness of changes that incorporate self-care attitudes.

\section{RESUMO}

Objetivo: Apreender as representações sociais sobre a aids construídas por mulheres privadas de liberdade. Método: Estudo descritivo, com abordagem quali-quantitativa que envolveu 174 apenadas de Presídio Feminino situado em capital do nordeste brasileiro. Aplicouse o Teste de Associação Livre de Palavras, em outubro e novembro de 2014, utilizando-se do estímulo aids. O corpus foi processado pelo software Iramuteq, sendo efetuadas a Classificação Hierárquica Descendente e Análise Fatorial de Correspondência. Resultados: Os conteúdos que compõem a representação social sobre aids são influenciados pelo contexto prisional, permeado de desassistência, desconhecimento, discriminação e condições de sofrimento, revelando fatores de vulnerabilidade ao HIV/Aids como atividade sexual desprotegida e compartilhamento de objetos; reiterando o estigma e o temor à doença; e favorecendo e sustentando sentimentos negativos e de rejeição. Conclusão: Considerar este amálgama representacional na garantia de um cuidado integral e contextualizado pode contribuir para redirecionar práticas, motivar condutas de autocuidado e reduzir atitudes preconceituosas.

\section{DESCRITORES}

Síndrome de Imunodeficiência Adquirida; Prisioneiros; Mulheres; Vulnerabilidade em Saúde.

\section{RESUMEN}

Objetivo: Aprehender las representaciones sociales acerca del Sida construidas por mujeres privadas de libertad. Método: Estudio descriptivo, con abordaje cualitativo y cuantitativo que involucró a 174 apenadas de Presidio Femenino ubicado en capital del nordeste brasileño. Se aplicó la Prueba de Asociación Libre de Palabras, en octubre y noviembre de 2014, utilizándose el estímulo Sida. El corpus fue procesado por el software Iramuteq, siendo llevados a cabo la Clasificación Jerárquica Descendiente y el Análisis Factorial de Correspondencia. Resultados: Los contenidos que componen la representación social acerca del Sida los influencia el contexto carcelario, permeado por desasistencia, desconocimiento, discriminación y condiciones de sufrimiento, revelando factores de vulnerabilidad al VIH/ Sida como actividad sexual desprotegida y el acto de compartir objetos, lo que reitera el estigma y el temor a la enfermedad y favorece y sostiene sentimientos negativos y de rechazo. Conclusión: Considerar ese amalgama representativo en la garantía de un cuidado integral y contextualizado puede contribuir para redirigir prácticas, motivar conductas de autocuidado y reducir actitudes prejuiciosas.

\section{DESCRIPTORES}

Síndrome de Inmunodeficiencia Adquirida; Prisioneros; Mujeres; Vulnerabilidad em Salud.

\section{REFERENCES}

1. UNAIDS Brasil. Programa Conjunto das Nações Unidas sobre HIV Aids [Internet]. Brasília; 2015 [citado 2015 dez. 20]. Disponível em: http://www.unaids.org.br/

2. Paschoal EP, Santo CCE, Gomes AMT, Santos El, Oliveira DC, Pontes APM. Adherence to antirretroviral therapy and its representations for people living with HIV/AIDS. Esc Anna Nery. 2014;18(1):32-40.

3. Gois SM, Santos Junior HPO, Silveira MFA, Gaudêncio MMP. Para além das grades e punições: uma revisão sistemática sobre a saúde penitenciária. Ciênc Saúde Coletiva. 2012;17(5):1235-46.

4. Justo AM, Camargo BV. Corpo e cognições sociais. Liber [Internet]. 2013 [citado 2015 dez. 20];19(1):21-32. Disponível em: http://www. scielo.org.pe/pdf/liber/v19n1/a03v19n1.pdf

5. Gomes AMT, Oliveira DCD, Santos ÉID, Santo CCE, Valois BRG, Pontes APMD. As facetas do convívio com o HIV: formas de relações sociais e representações sociais da AIDS para pessoas soropositivas hospitalizadas. Esc Anna Nery [Internet]. 2012 [citado 2015 dez. 20];16(1):111-20. Disponível em: http://www.scielo.br/pdf/ean/v16n1/v16n1a15.pdf

6. Gomes AMT, Silva EMP, Oliveira DC. Social representations of AIDS and their quotidian interfaces for people living with HIV. Rev Latino Am Enfermagem. 2011;19(3):485-92.

7. Sousa PJ, Ferreira LOC, Sá JB. Estudo descritivo da homofobia e vulnerabilidade ao HIV/Aids das travestis da Região Metropolitana de Recife, Brasil. Ciênc Saúde Coletiva. 2013;18(8):2239-51.

8. Oliveira NAI, Ribeiro SG, Lessa PRA, Monte AS, Bernardo EBR, Pinheiro AKB. Knowledge, attitude and practices regarding condom use among women prisoners: the prevention of STD/HIV in the prison setting. Rev Esc Enferm USP [Internet]. 2012 [cited 2016 Feb 19];46(3):711-9. Available from: http://www.scielo.br/pdf/reeusp/v46n3/en_25.pdf

9. Moscovici S. Representações sociais: investigações em psicologia social. Petrópolis: Vozes; 2012. 
10. Doise W. L'ancrage dans les études sur les représentations sociales. Bull Psychol. 1992;45(405):189-95.

11. Moreira ASP, Camargo BV, organizadores. Contribuições para a teoria e o método de estudos das representações sociais. João Pessoa: Ed. Universitária UFPB; 2007.

12. De Rosa AS. A rede associativa: uma técnica para captar a estrutura, os conteúdos, e os índices de polaridade, neutralidade e estereotipia dos campos semânticos relacionados com as representações sociais. In: Moreira ASP, Camargo BV, Jesuíno JC, Nóbrega SM, editoras. Perspectivas teórico-metodológicas em representações sociais. João Pessoa: Ed. Universitária UFPB; 2005. p. 61-127.

13. Ratinaud P. IRAMUTEQ: Interface de R pour les analyses multidimensionnelles de textes et de questionnaires [computer software]. 2009 [cited 2015 Feb 5]. Available from: http://www.iramuteq.org

14. Camargo BV, Justo AM. IRAMUTEQ: um software gratuito para análise de dados textuais. Temas Psicol [Internet]. 2013 [citado 2015 fev. 9];21(2):513-18. Disponível em: http://pepsic.bvsalud.org/pdf/tp/v21n2/v21n2a16.pdf

15. Parker R. Stigma, prejudice and discrimination in global public health. Cad Saúde Pública. 2012;28(1):164-9.

16. Costa TL, Oliveira DC, Formozo GA. Qualidade de vida e AIDS sob a óticsa de pessoas vivendo com o agravo: contribuição da abordagem estrutural das representações sociais. Cad Saúde Pública. 2015;31(2):365-76.

17. Cunha GH, Fiuza MLT, Gir E, Aquino PS, Pinheiro AKB, Galvão MTG. Quality of life of men with AIDS and the model of social determinants of health. Rev Latino Am Enfermagem. 2015;23(2):183-91.

18. Oliveira LV, Costa GMC, Medeiros KKAS, Cavalcanti AL. Epidemiological profile of female detainees in the Brazilian state of Paraíba: a descriptive study. Online Braz J Nurs [Internet]. $2013 \quad$ [cited 2015 June 30];12(4):892-901. Available from: http://dx.doi. org/10.5935/1676-4285.20134284.

19. Andrade SSC, Zaccara AAL, Leite KNS, Brito KKG, Soares MJGO, Costa MML, et al. Knowledge, attitude and practice of condom use by women of an impoverished urban área. Rev Esc Enferm USP [Internet]. 2015 [cited 2016 May 13];49(3):364-71. Available from: http:// www.scielo.br/pdf/reeusp/v49n3/0080-6234-reeusp-49-03-0364.pdf

20. Oliveira DC. Construction and transformation of social representations of AIDS and implications for health care. Rev Latino Am Enfermagem. 2013;21(n.spe):276-86

21. Alvarenga WA, Dupas G. Experience of taking care of children exposed to HIV: a trajectory of expectations. Rev Latino Am Enfermagem. 2014;22(5):848-56.

22. Soares GB, Garbin CAS, Rovida TAS, Garbin AJI. Quality of life of people living with HIV/AIDS treated by the specialized service in VitóriaES, Brazil. Ciênc Saúde Coletiva. 2015;20(4):1075-84.

23. Lowther K, Selman L, Harding R, Higginson IJ. Experience of persistent psychological symptoms and perceived stigma among people with HIV on antiretroviral therapy (ART): a systematic review. Int J Nurs Stud. 2014;51(8):1171-89.

24. Renesto HMF, Falbo AR, Souza E, Vasconcelos MG. Coping and perception of women with HIV infection. Rev Saúde Pública. $2014 ; 48(1): 36-42$.

25. Strauss M, Rhodes B, George G. A qualitative analysis of the barriers and facilitators of HIV counselling and testing perceived by adolescents in South Africa. BMC Health Serv Res [Internet]. 2015 [cited 2015 June 30];15:250. Available from: http://www.ncbi.nlm.nih.gov/pmc/ articles/PMC4484707/ 